\title{
The Faces of Judicial Integrity. An Introduction
}

$\mathrm{T}$ he present thematic volume of The Critique of Law features articles inspired by the discussion sessions that took place during the conference titled Integralność sędziego i petnomocnika procesowego [The Integrity of a Judge and of a Lawyer] ${ }^{1}$, organised by the Institute of Legal Ethics. The issue is, to some degree, a continuation of studies into the subjectivity and the responsibility of lawyers in a world of institutions, conducted earlier at the Institute. ${ }^{2}$

One of the issues that emerged at that time concerned integrity as: 1) identity, being oneself regardless of the number of (sometimes conflicting) roles performed in the sphere of everyday life. In this sense, integrity means the ability to remain autonomous in the face of the demands of the social norms in which we are embedded; 2 ) an attitude of honesty understood in a particular way: as fidelity to one's own moral convictions, which is manifested in the actions of the subject. In this perspective, integrity is defined as the consistency of one's beliefs and actions, while its opposite is hypocrisy.

When referring to these definitions, underlying the discussion on legal professions, we decided it was reasonable to explore the category of integrity with particular reference to the profession of a judge in more detail. This belief is strengthened as a result of the Polish discussion on the role of a judge in the context of rule of law, which has been especially heated in recent time. It makes the problem of judicial integrity become a valid subject not only for theoretical but also for practical reasons. Addressing this subject may be thus understood as an attempt to answer these problems by bringing them into the spotlight.

Integrity is an essential notion in the discussion on the role of a judge and of a lawyer (advocate, legal counsel), which has been reflected in the volume. In the

1 The conference titled Integralność sędziego i petnomocnika procesowego took place on 5 March and was organised by the Institute of Legal Ethics in an online format.

2 Texts featured in: Archiwum Filozofii Prawa i Filozofii Spotecznej 2018, issue 1, which is a thematic issue titled Etyka prawnicza. Działanie prawników w świecie instytucji [EN: Legal Ethics. The Activity of Lawyers in a World of Institutions]. 
case of the abovementioned roles, significant from the perspective of using law as a mechanism of organising human relationships, we have to do with an individual operating within institutional structures. An individual, by accepting certain professional roles, faces a claim requiring them to accept the duty to act in accordance with the objectives and rules of a given institution. But there may occur a conflict between institutional morality and individual morality - not to mention the expectations of the public. A conflict exists also when an individual plays several roles which require them to engage in contradictory behaviours. The clearer the difference between the standard social practices and an individual's system of values, the harder it is for the individual to integrate the different roles they have taken on. An important thing to add here is that practicing a given profession often involves anxiety and tension resulting from the expectations of particular parties of interaction. For this reason, maintaining autonomy and the ability to judge one's own actions and objectives and the standard (institutional) social practices in which we engage becomes all the more important.

An individual's actions may be considered in the light of their compliance with institutional requirements, their consistency with one's own beliefs, their ability to satisfy the expectations of the public or the parties of litigation. Differences in the assessments made by different actors in different contexts can be a problem. This is why we have made it the central point of this volume. The role of a judge is to exercise one of the powers in a constitutional state, which makes their integrity a public matter. The practical repercussions of a judge's strive to maintain it as well as the consequences of the lack of it affect not only the judge but also citizens. Referring to Ronald Dworkin's theory, one could say it is an issue which is fundamental also to the principles on which the entire political community is based. We wish to distinguish moral, political, and religious integrity as components of its general concept.

What we consider important, among others, are the questions about the freedom of speech: are judges allowed to use moral and political arguments in interpreting and applying law? Should judges be able to reveal their views and criticise other authorities? Finally, what circumstances affect one's ability to maintain integrity as a judge?

The objective of this volume is, however, not to offer a single way of understanding of the matter of integrity, internally consistent in terms of methodology and issues addressed. Instead, we focus on showing the different faces of integrity of judges (in particular), which is a product of individual standpoints and problems.

Encouraging you to read on, we would like to thank the editorial board of The Critique of Law - and Professor Jolanta Jabłońska-Bonca in particular - for the interest in publishing this thematic issue. Thanks to the kindliness and assistance 
offered to us by the entire editorial board, it was possible to publish this volume. It was also possible thanks to the involvement of the authors, whom we would like to thank for the participation in the conference and for the submitted texts. We would also like to thank the participants of the conference for the interesting discussion. The final version of the publication, in terms of both content and form, is the outcome of the feedback provided by its reviewers, whom we would like to sincerely thank as well.

$$
* * *
$$

When we were planning the debate on the integrity of a judge and of a lawyer as part of preparations to the aforementioned conference, we wished to see Professor Ryszard Sarkowicz take part in it. Yet, his untimely passing away made it impossible. We would like to dedicate this volume to Professor Ryszard Sarkowicz, whose works on legal ethics have influenced our interest in legal professions, and are still present in our discussions. ${ }^{3}$

Przemysław Kaczmarek, Paweł Skuczyński

Wrocław-Warsaw, September 2021

3 In this context, Ryszard Sarkowicz's book titled Amerykańska etyka prawnicza (Zakamycze 2004) deserves a particular mention. 